\title{
Hepatic oxidative stress in an animal model of sleep apnoea: effects of different duration of exposure
}

\author{
Darlan P Rosa ${ }^{1 *}$, Denis Martinez ${ }^{1}$, Jaqueline N Picada², Juliane G Semedo² and Norma P Marroni ${ }^{1,2}$
}

\begin{abstract}
Background: Repeated apnoea events cause intermittent hypoxia $(\mathrm{IH})$, which alters the function of various systems and produces free radicals and oxidative stress.

Methods: We investigated hepatic oxidative stress in adult mice subjected to intermittent hypoxia, simulating sleep apnoea. Three groups were submitted to 21 days of $\mathbb{H}(\mathrm{IH}-21)$, 35 days of $\mathbb{H}(\mathrm{IH}-35)$, or 35 days of sham $\mathrm{H}$. We assessed the oxidative damage to lipids by TBARS and to DNA by comet assay; hepatic tissue inflammation was assessed in HE-stained slides. Antioxidants were gauged by catalase, superoxide dismutase, glutathione peroxidase activity and by total glutathione.
\end{abstract}

Results: After $\mid \mathrm{H}-21$, no significant change was observed in hepatic oxidative stress. After $\mathrm{IH}-35$, significant oxidative stress, lipid peroxidation, DNA damage and reduction of endogenous antioxidants were detected.

Conclusions: In an animal model of sleep apnoea, intermittent hypoxia causes liver damage due to oxidative stress after 35 days, but not after 21 days.

\section{Background}

In obstructive sleep apnoea (OSA), pharyngeal occlusion occurs, typically for 10 to 40 seconds, causing a decrease of $\mathrm{PaO}_{2}$ and an increase in $\mathrm{PaCO}_{2}$, ending with an arousal [1]. Intermittent hypoxia due to OSA causes oxidative stress, a recognized mechanism in the nonalcoholic fatty liver disease (NAFLD), which may progress to nonalcoholic steatohepatitis (NASH) [2].

Intermittent hypoxia $(\mathrm{IH})$ increases liver damage [3]. During hypoxia, activation of xanthine oxidase [4], NAPDH oxidase [5], and phospholipase $A_{2}$ [6] occurs, forming reactive oxygen species (ROS). Increased ROS and decreased antioxidant capacity [7-9] induce oxidative stress [10]. In hypoxia, superoxide anions are formed, which, together with nitric oxide (NO), the main vasodilator, produce peroxynitrite [11-13]. This reaction reduces the bioavailability of $\mathrm{NO}$, attenuating NO-dependent vasodilation, capillary perfusion and expression of adhesion molecules [14-17].

\footnotetext{
* Correspondence: darlanpr@yahoo.com.br

'Programa de Pós-Graduação em Medicina: Ciências Médicas, Universidade Federal do Rio Grande do Sul, Rio Grande do Sul, Brasil

Full list of author information is available at the end of the article
}

The formation of ROS in OSA is similar to what occurs in ischemia-reperfusion [18]. Oxidative stress leads to inflammation, recognised as a mechanism of the pathophysiology of OSA [19]. Excessive formation of ROS leads to lipid peroxidation in cell membranes, protein oxidation and DNA damage [20-22]. Several ROS are formed in hepatocytes through the activation of Kupffer cells and inflammatory cells [23].

Another group has exposed mice to IH and to a highcholesterol diet for 6 months, revealing the involvement of OSA in non-alcoholic steatohepatitis (NASH) [3]. IH aggravates paracetamol-induced liver damage after 21 days [24]. To understand the mechanisms leading to NAFLD and NASH it may relevant to identify the time frame in which these phenomena occur. There are, however, no studies specifically investigating the duration of $\mathrm{IH}$ exposure that causes liver damage in an animal model of sleep apnoea. This knowledge will be relevant to help design future studies.

The aim of the present study was to establish the duration of exposure to intermittent hypoxia necessary and sufficient to trigger liver damage and oxidative stress in mice.

\section{Biomed Central}

() 2011 Rosa et al; licensee BioMed Central Ltd. This is an Open Access article distributed under the terms of the Creative Commons Attribution License (http://creativecommons.org/licenses/by/2.0), which permits unrestricted use, distribution, and reproduction in any medium, provided the original work is properly cited. 


\section{Methods}

The experimental procedures complied with the rules established by the "Research in Health and Animal Rights" according to the Commission of Research and Ethics in Health of the Research and Postgraduate Group of the Hospital de Clínicas de Porto Alegre.

Thirty-six male CF-1 mice (8-11 weeks old) from Fundação Estadual de Produção e Pesquisa (FEPPS) were employed. They were kept at the Animal Experimentation Unit of the Research Center of the Hospital de Clínicas of Porto Alegre in plastic boxes measuring $30 \times$ $19 \times 13 \mathrm{~cm}$ lined with wood chips, in a 12-hour dark/ light cycle (light from 7 a.m. to 7 p.m.) at a temperature of $224^{\circ} \mathrm{C}$. The mice were given food (Purina-Nutripal, Porto Alegre, RS, Brazil) and water ad libitum.

The animals were randomly divided into three groupings $(\mathrm{n}=12)$ : group $\mathrm{SIH}$, sham intermittent hypoxia, which underwent the simulated procedure; group $\mathrm{IH}-21$, exposed to hypoxia for 21 days; and group IH-35, exposed hypoxia for 35 days.

$\mathrm{IH}$ procedures were described in detail before [25]. In brief, during five weeks, 7 days per week, 8 hours a day, from 9 a.m. to 5 p.m., in the lights-on period, the rodents were placed in the cages (Figure 1). A mixture with $90 \%$ nitrogen and $10 \% \mathrm{CO}_{2}$ was released in the hypoxia chamber, for 30 seconds. The gas mixture reduced the oxygen fraction from $21 \%$ to approximately $8 \%$ and the $\mathrm{CO}_{2}$ fraction to $6 \%$. Subsequently, a fan insufflated room air in the chamber for 30 seconds, restoring the oxygen fraction to $21 \%$. Each hypoxia/normoxia cycle lasted for 60 seconds; in 8 hours, $480 \mathrm{IH}$ periods occurred, equivalent to an apnea index of 60 per hour.

The SIH group was housed in an adjacent cage and underwent the same fan activity as the IH group, but no gas was introduced in the cage during the hypoxia cycle (Figure 1).

On the 21 st or 35 th day, the animals were killed. They were first anaesthetised with ketamine hydrochloride (100 mg/kg) and xylazine hydrochloride (50 mg/kg ip). Blood was collected from the retro-orbital vein with the aid of a heparinised glass capillary [26] to complete the hepatic integrity (AST, ALT and ALP) test and comet assay. We removed the liver of animals for histological analysis; the rest were frozen $-80^{\circ} \mathrm{C}$ for later biochemical analysis. The animals were euthanized by exsanguination under deep anaesthesia [27,28].

Nine millilitres of phosphate buffer (140 mM KCL, 20 $\mathrm{mM}$ phosphate, $\mathrm{pH}$ 7.4) per tissue gram was added, and tissue was homogenised in an Ultra Turrax at $4^{\circ} \mathrm{C}$. Next, it was centrifuged for 10 minutes at 4,000 rpm (2150.4 g). The samples were stored again at $-80^{\circ} \mathrm{C}$ for posterior analyses.

We used the Bradford method to quantify protein, with bovine albumin as the standard $\left(\operatorname{Sigma}^{(\mathbb{R}}\right)$. The samples were measured spectrophotometrically at 595 $\mathrm{nm}$, and values expressed in $\mathrm{mg} / \mathrm{g}$ liver [29] were used to calculate values of TBARS (thiobarbituric acid-reactive substances) and antioxidant enzymes.

The amount of aldehydes generated by lipid peroxidation is measured by the TBARS method, which measures the amount of substances reacting with thiobarbituric acid. The samples were incubated at $100^{\circ}$ $\mathrm{C}$ for 30 minutes after addition of $0.37 \%$ thiobarbituric acid in $15 \%$ trichloroacetic acid and centrifuged at 3000 rpm (1612.8 g) for 10 minutes at $4^{\circ} \mathrm{C}$. Absorbance was determined spectrophotometrically at $535 \mathrm{~nm}$ [30].

The analysis of SOD is based on the inhibition of the reaction of the superoxide radical with adrenaline [31].

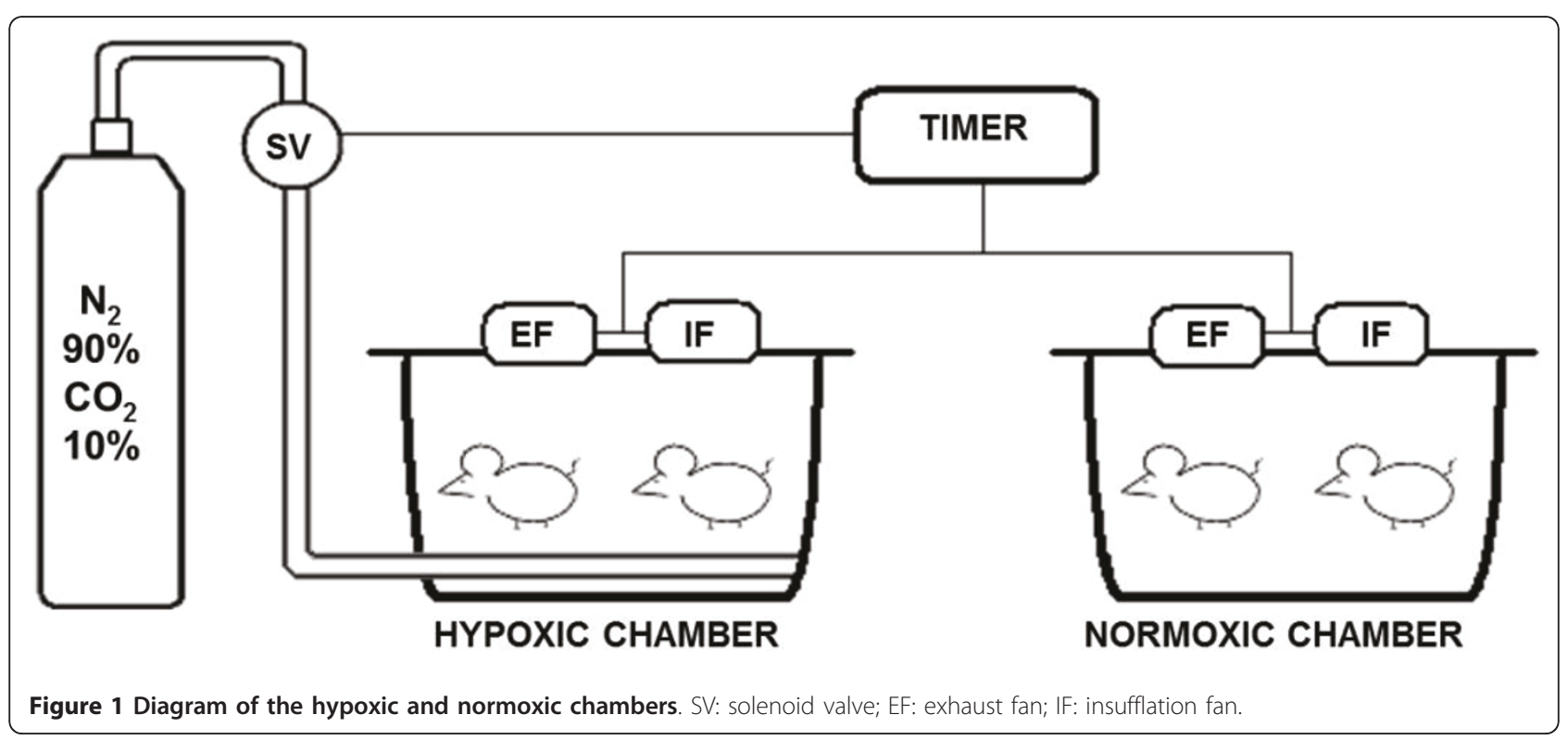


The auto-oxidation rate of epinephrine, which is progressively inhibited by increasing amounts of SOD in the homogenate, was monitored spectrophotometrically at $480 \mathrm{~nm}$. The amount of enzyme that inhibited $50 \%$ of epinephrine auto-oxidation was defined as $1 \mathrm{U}$ of SOD activity.

The analysis of CAT activity is based on measuring the decrease in hydrogen peroxide [32]. Catalase activity was determined by measuring the decrease in absorption at $240 \mathrm{~nm}$ in a reaction medium containing $50 \mathrm{mM}$ phosphate buffer saline ( $\mathrm{pH} 7.2$ ) and 0.3 M hydrogen peroxide. The enzyme activity was assayed spectrophotometrically at $240 \mathrm{~nm}$.

The activity of GPx is based on the consumption of $\mathrm{NADPH}$ in the reduction of oxidised glutathione [33]. The glutathione peroxidase activity was determined by the oxidation rate of NADPH in the presence of reduced glutathione and glutathione reductase. Sodium azide was added to inhibit catalase activity. The GPx activity was measured with a spectrophotometer at 340 nm.

Total glutathione (GSH), a water soluble non-enzymatic antioxidant, [34] was measured as described previously [35], in a reaction medium consisting of a solution of $300 \mathrm{mM}$ phosphate buffer (Na2HPO4.1H2O) and a solution of dithionitrobenzoic acid (DTNB). The reaction products were read at $412 \mathrm{~nm}$.

The alkaline comet assay was carried out as described in [36], with minor modifications [37]. The liver tissue samples (200-250 mg) were placed in $0.5 \mathrm{~mL}$ of cold phosphate-buffered saline (PBS) and finely minced in order to obtain a cell suspension; the blood samples (50 $\mu \mathrm{L}$ ) were placed in $5 \mu \mathrm{L}$ of anti-coagulant (heparin sodium 25.000 UI- Liquemine $\left.{ }^{\circledR}\right)$. Liver and blood cell suspensions $(5 \mu \mathrm{L})$ were embedded in $95 \mu \mathrm{L}$ of $0.75 \%$ low melting point agarose (Gilco BRL) and spread on agarose-precoated microated microscope slides. After solidification, slides were placed in lysis buffer $(2.5 \mathrm{M}$ $\mathrm{NaCl}, 100 \mathrm{mM}$ EDTA an $10 \mathrm{mM}$ Tris, $\mathrm{pH} 10.0$ ), with freshly added 1\% Triton X-100 (Sigma) and 10\% DMSO for $48 \mathrm{~h}$ at $4^{\circ} \mathrm{C}$. The slides were subsequently incubated in freshly prepared alkaline buffer $(300 \mathrm{mM} \mathrm{NaOH}$ and $1 \mathrm{mM}$ EDTA, pH > 13) for $20 \mathrm{~min}$, at $4^{\circ} \mathrm{C}$. An electric current of $300 \mathrm{~mA}$ and $25 \mathrm{~V}(0.90 \mathrm{~V} / \mathrm{cm})$ was applied for $15 \mathrm{~min}$ to perform DNA electrophoresis. The slides were then neutralized ( $0.4 \mathrm{M}$ Tris, $\mathrm{pH} 7.5)$, stained with silver and analyzed using microscope. Images of 100 randomly select cells (50 cells from each of two replicate slides) were analyzed from each animal. Cells were also visually scored according to tail size into five classes ranging from undamaged (0) to maximally damage (4), resulting in a single DNA damage score to each animal, and consequently to each studied group. Therefore, the damage index (DI) can range from 0 (completely undamaged, 100 cells $\times 0$ ) to 400 (with maximum damage, $100 \times 4)$. Damage frequency $(\%)$ was calculated based on the number of tailed versus tailless cells.

The levels of nitrates and nitrites were measured by the reaction of the samples with Griess reagent. Aliquots of $50 \mu \mathrm{L}$ were incubated with enzyme cofactors and nitrate reductase for 30 minutes at room temperature for the conversion of nitrate to nitrite. The nitrite formed was then analysed by reaction with the Griess reagent, forming a coloured compound that was measured by spectrophotometer at a wavelength of $540 \mathrm{~nm}$ [38].

For histological evaluation, part of the liver was preserved in $10 \%$ formalin for 24 hours, embedded in paraffin, and cut into $6-\mu \mathrm{m}$ thick sections with a microtome. Sections were stained with hematoxylin and eosin.

The results are expressed as mean \pm standard error. We used ANOVA and the Student-Newmann-Keuls or Student's t-test for comparing groups. The significance level was $5 \%(\mathrm{p}<0.05)$.

\section{Results}

The circulating levels of the liver enzymes aspartate aminotransferase (AST), alanine amino transferase (ALT), and alkaline phosphatase (ALP), parameters of liver damage, showed no significant difference between the $\mathrm{IH}-21$ group and the SIH. The IH-35 group showed significantly increased levels $(\mathrm{p}<0.05)$ compared to the sham intermittent hypoxia group (Table 1).

Lipid peroxidation measured by the TBARS technique showed no oxidative damage in group IH-21 compared to SIH. However, there was significant damage in the lipid peroxidation in liver subjected to hypoxia for 35 days (Figure 2). Evaluation of the antioxidant enzymes showed a significant decrease in the activities of superoxide dismutase (SOD), glutathione peroxidase (GPx) and catalase (CAT) in liver tissue with intermittent hypoxia for 35 days (Table 2). The quantification of total endogenous glutathione in the liver showed a significant decrease in the 35-day hypoxia group compared with the sham intermittent hypoxia (Figure 3). These results demonstrate that $\mathrm{IH}$ induced a decrease in the endogenous antioxidant defence.

Table 1 Enzymes indicating hepatic integrity: AST, ALT and alkaline phosphatase.

\begin{tabular}{lccc}
\hline Enzymes & SIH & IH-21 & IH-35 \\
\hline AST $_{(\mathrm{U} / L)}$ & $124.4 \pm 6.5$ & $94.36 \pm 7.05$ & $145.8 \pm 7.2^{\mathrm{a}}$ \\
$\mathrm{ALT}_{(\mathrm{U} / \mathrm{L})}$ & $45.5 \pm 4.0$ & $48.50 \pm 2.85$ & $55.6 \pm 1.3^{\mathrm{b}}$ \\
$\mathrm{AP}_{(\mathrm{U} / \mathrm{L})}$ & $97.7 \pm 3.1$ & $84.25 \pm 1.98$ & $122.6 \pm 2.4^{\mathrm{c}}$ \\
\hline
\end{tabular}

Data are presented as mean \pm standard error $\left(\mathrm{n}=12\right.$ animals/group). ${ }^{\mathrm{a}} \mathrm{IH}-35$ vs $\mathrm{SIH}, \mathrm{p}=0,04{ }^{\mathrm{b}}{ }^{\mathrm{IHH}}-35$ vs $\mathrm{SIH}, \mathrm{p}=0,03 ;{ }^{c} \mathrm{IH}-35$ vs $\mathrm{SIH}, \mathrm{p}<0,0001$. $\mathrm{SIH}$ : sham intermittent hypoxia group; $\mathrm{HH}-21$ : intermittent hypoxia for 21 days; $\mathrm{IH}-35$ :

intermittent hypoxia for 35 days; AST: aspartate aminotransferase; ALT: alanine aminotransferase; ALP: alkaline phosphatase. 


\section{TBARS}

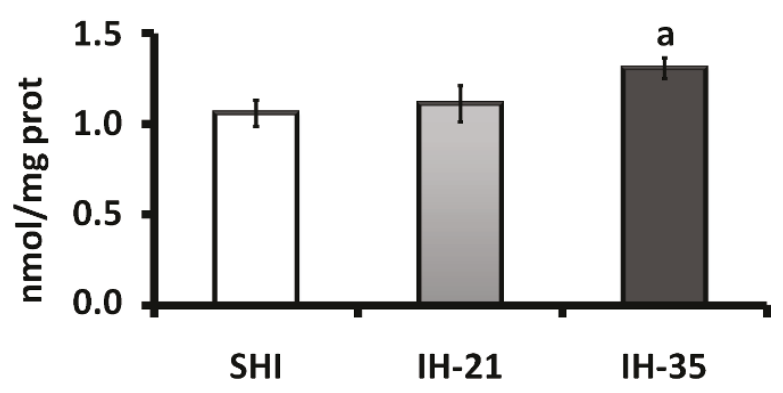

Figure 2 Effect of intermittent hypoxia on hepatic lipid peroxidation, evaluated using the TBARS assay. Data are mean \pm standard error of the mean ( $n=12$ animals/group). ${ }^{a}, p=0.0182$ vs. SIH. SIH: sham intermittent hypoxia group; $\mathrm{IH}-21$ : intermittent hypoxia for 21 days; $1 \mathrm{H}-35$ : intermittent hypoxia for 35 days.

The assessment of DNA damage by the comet assay showed that the damage in blood did not differ between groups, but the liver tissue exhibited a significant increase in DNA damage in group IH-35 compared with SIH (Table 3).

In the assessment of metabolites of nitric oxide in liver tissue of mice subjected to $\mathrm{IH}$ for 35 days, we noted a significant increase in $\mathrm{NO}$ in these animals compared with SIH (Table 4).

Several histological liver changes were also observed in animals of the IH-35 group - ballooning, steatosis, necrosis and the presence of neutrophils -when compared with mice under sham intermittent hypoxia (Figures 4 and 5).

\section{Discussion}

We report for the first time that 35 but not 21 days of exposure to $\mathrm{IH}$, simulating an OSA of 60 events per hour, reducing for $6 \%$ the concentration of oxygen, causes hepatic damage. This is also the first report to combine the description of enzyme, lipid, DNA, oxidative, and nitrosative hepatic damage. We used an experimental model that produces levels of hypoxia comparable to those observed in patients with severe OSA [24,39]. Although our findings cannot be immediately translated to the clinical setting, they are in agreement with the literature indicating an OSA-NASH association $[40,41]$.

Table 2 Activities of liver antioxidant enzymes

\begin{tabular}{lccc}
\hline Enzymes & SIH & IH-35 & p value \\
\hline SOD ${ }_{(\text {USOD/mg prot) }}$ & $4.63 \pm 0.26$ & $3.16 \pm 0.25$ & 0.0005 \\
GPX ${ }_{\text {(mmol/min/mg prot) }}$ & $1.00 \pm 0.11$ & $0.52 \pm 0.06$ & 0.0028 \\
CAT $_{\text {(pmol/mg prot) }}$ & $1.06 \pm 0.04$ & $0.79 \pm 0.03$ & 0.0003 \\
\hline
\end{tabular}

Data are mean \pm standard error ( $n=12$ animals/group). SIH: sham intermittent hypoxia group; $1 \mathrm{H}-35$ : intermittent hypoxia for 35 days. SOD: superoxide dismutase; GPx: glutathione peroxidase; CAT: catalase.

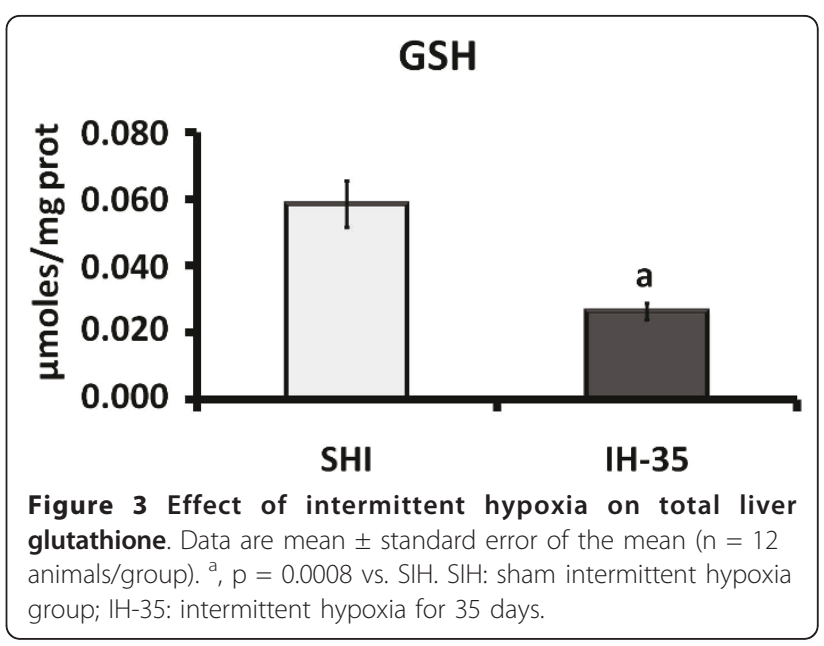

Two mechanisms are proposed for the morbidity caused by OSA: the activation of inflammatory factors and oxidative stress $[42,43]$, which also can be modulated by genetic, lifestyle and environmental factors $[43,44]$. Oxidative stress plays an important role in various diseases as well as in OSA, which causes an effect similar to ischemia-reperfusion [18] in which there is activation of xanthine oxidase, leading to the formation free radicals and further imbalance between oxidants and antioxidants [4-6].

The analysis of liver integrity showed that the liver tissue of mice subjected to intermittent hypoxia was damaged, but only after 35 days, as demonstrated by the significant increase in circulating AST, ALT and alkaline phosphatase. The present results demonstrate damage both at cytoplasmic and mitochondrial level, confirmed by the presence in the histological examination of ballooning, steatosis, necrosis and the presence of neutrophils in the liver, similar to what is observed in NASH [45].

In the evaluation of hepatic lipid peroxidation, we observed a significant increase in lipid oxidative damage in animals that were subjected to hypoxia for 35 days, as indicated by the TBARS test, but not in group IH-21.

Table 3 Comet assay on peripheral blood and liver tissues from mice subjected to hypoxia

\begin{tabular}{ccccc}
\hline Tissue & $\begin{array}{c}\text { Damage } \\
\text { index }^{\mathbf{a}}\end{array}$ & $\begin{array}{c}\text { Damage } \\
\text { frequency }^{\mathbf{b}}\end{array}$ & $\begin{array}{c}\text { Damage } \\
\text { index }\end{array}$ & $\begin{array}{c}\text { Damage } \\
\text { frequency }\end{array}$ \\
\hline Blood & $15.3 \pm 4.4$ & $7.6 \pm 1.3$ & $19.3 \pm 4.1$ & $8.0 \pm 1.4$ \\
Liver & $38.1 \pm 5.1$ & $14.8 \pm 1.8$ & $114.7 \pm 32.3^{* *}$ & $43.2 \pm 11.3^{* *}$ \\
\hline
\end{tabular}

Data are presented as mean \pm standard error ( $n=6$ animals/group). SIH: sham intermittent hypoxia group; $\mathrm{IH}-35$ : intermittent hypoxia for 35 days. ${ }^{\mathrm{a}}$, Damage index: can range from 0 (completely undamaged, 100 cells $\times 0$ ) to 400 (with maximum damage, $100 \times 4$ ). ${ }^{b}$, Damage frequency: calculated based on the number of cells with tails versus those with no tail. ${ }^{* *}, p<0.01$, statistically significant difference from sham intermittent hypoxia group (t-test). 
Table 4 Quantification of nitric oxide metabolites in liver tissue

\begin{tabular}{lccc}
\hline Metabolites & SIH & IH-35 & p value \\
\hline $\mathrm{NO}_{2(\mu \mathrm{mol} / \mathrm{L})}$ & $2.128 \pm 0.202$ & $3.405 \pm 0.112$ & 0.0001 \\
$\mathrm{NO}_{3(\mu \mathrm{mo} / \mathrm{L})}$ & $0.018 \pm 0.002$ & $0.050 \pm 0.003$ & 0.0001 \\
\hline
\end{tabular}

Data are mean \pm standard error of the mean ( $n=12$ animals/group). SIH: sham intermittent hypoxia group; $\mathrm{IH}-35$ : intermittent hypoxia for 35 days; $\mathrm{NO}_{2}$ : total nitrate; $\mathrm{NO}_{3}$ : nitrites.

This damage can be caused by the increase of free radicals in the liver tissue. Similar data have been reported in other studies of intermittent hypoxia [46-48] and by our laboratory in other experimental models of hepatic oxidative damage [49-54].

As we did not observe liver damage in animals exposed to IH for 21 days, by the liver enzyme, histological, or lipid peroxidation assays, we concluded that this duration of $\mathrm{IH}$ causes no damage to the organ. Therefore, dosages of antioxidant enzymes, comet assay and nitrites metabolites were not conducted in the $\mathrm{IH}$ 21 group.

Comet assay in liver tissue revealed a significant increase in DNA damage in the IH-35 group in comparison to the SIH group. No evidence of damage was observed in blood tissue. The rate of DNA damage detected by the comet assay depends on the tissue or organ analyzed [55]. Here, the DNA damage was observed only in the tissue most susceptible to lesions produced by $\mathrm{IH}$. In the alkaline version used, the comet assay detects a broad spectrum of DNA lesions, including single strand breaks [56,57].

Previous comet assay and TBARS data have demonstrated increased formation of free radicals in sleep apnoea patients [11]. Possibly, the formation of superoxide radical $\left(\mathrm{O}_{2}^{-\bullet}\right)$ and hydrogen peroxide $\left(\mathrm{H}_{2} \mathrm{O}_{2}\right)$, which

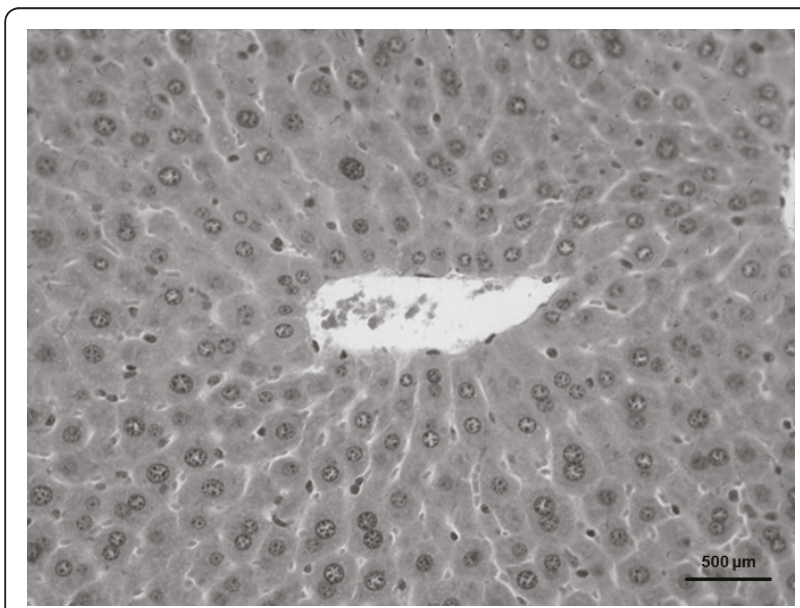

Figure 4 Photomicrograph of the mouse liver in sham intermittent hypoxia condition. A normal histological pattern was observed. Hematoxylin and eosin.

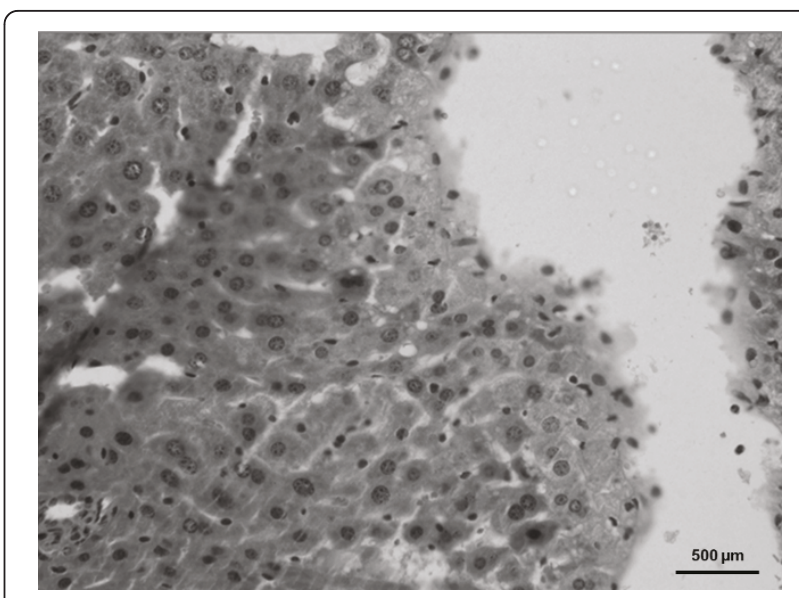

Figure 5 Photomicrograph of the mouse liver in intermittent hypoxia for $\mathbf{3 5}$ days. It was observed cellular ballooning, steatosis, necrosis and the presence of neutrophils. Hematoxylin and eosin.

appear to be increased in individuals with OSA, is due to the conversion of xanthine dehydrogenase (type D) into its oxidase (type $\mathrm{O}$ ) form in hypoxia, followed by the activation of the oxidase form during reoxygenation (normoxia) by the hypoxanthine formed during hypoxia. This xanthine oxidase activity generates $\mathrm{O}_{2}{ }^{-\bullet}, \mathrm{H}_{2} \mathrm{O}_{2}$, and uric acid $[4,11]$.

Our evaluation of the endogenous antioxidant liver enzymes SOD, GPx and CAT showed that their activities were significantly decreased in mice after 35 days under intermittent hypoxia. Quantification of total glutathione revealed significant decreases in the group exposed to intermittent hypoxia compared to $\mathrm{SIH}$, demonstrating a reduced hepatic antioxidant defence in these animals.

The increase in TBARS and decrease in endogenous antioxidants observed in the present study further promotes oxidative stress, contributing to aggravation of the liver tissue injury. This kind of pathological synergy is evidenced in experimental models of liver damage induced by xenobiotic agents that cause oxidative stress such as carbon tetrachloride and toluene $[49,50,52,54,58]$, by surgical procedures such as ligation of the common bile duct [51,53] or by thymoquinone [59].

The increased nitric oxide metabolites nitrite and nitrate in the livers of IH-35 mice confirms findings by other authors, who demonstrated a significant increase of nitric oxide in animals exposed to $\mathrm{IH}$ simulating OSA (6 min/6 min) during 120 days [48], and to hypobaric hypoxia during 32 days [60]. The increase of NO, along with increased free radicals, may generate nitrosative stress caused by the reaction products of these two substances, such as peroxide nitrite (OONO*) formed by the reaction between $\mathrm{NO}$ and $\mathrm{O}_{2}{ }^{-\bullet}[11]$. Much evidence indicates that oxidative and nitrosative 
stress have important roles in the complication of hypoxia [61].

OSA is usually accompanied by arterial hypertension, pulmonary hypertension, myocardial infarction and stroke, which may be due to changes in nitric oxide production [62]. Veasey et al. had demonstrated irreversible basal forebrain nitrosative damage as a possible cause for residual sleepiness in OSA [63].

It is increasingly clear that $\mathrm{IH}$ is capable of causing liver tissue damage. This was here demonstrated by several lines of evidence: elevated circulating levels of liver enzymes, NO increase, damage to lipids and DNA, and reduced endogenous antioxidant defences. Further translational research is necessary to completely correlate these findings with the NASH pathology.

\section{Conclusions}

The present results suggest that a model of intermittent hypoxia for 35 days, simulating sleep apnoea, is useful to investigate liver injury by oxidative and nitrosative stress. Exposure to intermittent hypoxia during 21 days may be insufficient to produce hepatic damage.

\section{Acknowledgements}

This research was supported by the Research Incentive Fund of the Hospital de Clínicas de Porto Alegre (HCPA-FIPE), the Coordination of Improvement of Higher Education Personnel (CAPES), the National Council of Scientific and Technological Development (CNPq) and the Lutheran University of Brazil (ULBRA).

\section{Author details}

${ }^{1}$ Programa de Pós-Graduação em Medicina: Ciências Médicas, Universidade Federal do Rio Grande do Sul, Rio Grande do Sul, Brasil. ${ }^{2}$ Programa de PósGraduação em Genética e Toxicologia, Universidade Luterana do Brasil, Rio Grande do Sul, Brasil.

\section{Authors' contributions}

DPR conducted the animal studies. DPR and JGS collected tissues and performed analyses. DPR and DM wrote the manuscript. JNP, NPM and DM reviewed the manuscript. DPR and DM designed the study and reviewed the manuscript. All the authors read and approved the final manuscript.

\section{Competing interests}

The authors declare that they have no competing interests.

Received: 14 July 2010 Accepted: 5 July 2011 Published: 5 July 2011

\section{References}

1. Dempsey JA, Veasey SC, Morgan BJ, O'Donnell CP: Pathophysiology of sleep apnea. Physiol Rev 2010, 90:47-112.

2. Mishra P, Nugent C, Afendy A, Bai C, Bhatia P, Afendy M, Fang Y, Elariny H, Goodman Z, Younossi ZM: Apnoeic-hypopnoeic episodes during obstructive sleep apnoea are associated with histological nonalcoholic steatohepatitis. Liver Int 2008, 28:1080-1086.

3. Savransky V, Bevans S, Nanayakkara A, Li J, Smith PL, Torbenson MS, Polotsky VY: Chronic intermittent hypoxia causes hepatitis in a mouse model of diet-induced fatty liver. Am I Physiol Gastrointest Liver Physiol 2007, 293:G871-877.

4. Sohn HY, Krotz F, Gloe T, Keller M, Theisen K, Klauss V, Pohl U: Differential regulation of xanthine and $\mathrm{NAD}(\mathrm{P}) \mathrm{H}$ oxidase by hypoxia in human umbilical vein endothelial cells. Role of nitric oxide and adenosine. Cardiovascular research 2003, 58:638-646.
5. Jones RD, Hancock JT, Morice AH: NADPH oxidase: a universal oxygen sensor? Free radical biology \& medicine 2000, 29:416-424.

6. Neidlinger NA, Hirvela ER, Skinner RA, Larkin SK, Harken AH, Kuypers FA: Postinjury serum secretory phospholipase A2 correlates with hypoxemia and clinical status at 72 hours. Journal of the American College of Surgeons 2005, 200:173-178.

7. Christou K, Moulas AN, Pastaka C, Gourgoulianis Kl: Antioxidant capacity in obstructive sleep apnea patients. Sleep medicine 2003, 4:225-228.

8. Lavie L, Vishnevsky A, Lavie P: Evidence for lipid peroxidation in obstructive sleep apnea. Sleep 2004, 27:123-128.

9. Barcelo A, Barbe F, de la Pena M, Vila M, Perez G, Pierola J, Duran J, Agusti AG: Antioxidant status in patients with sleep apnoea and impact of continuous positive airway pressure treatment. Eur Respir $J$ 2006, 27:756-760.

10. Pialoux V, Mounier R, Brown AD, Steinback CD, Rawling JM, Poulin MJ: Relationship between oxidative stress and HIF-1 alpha mRNA during sustained hypoxia in humans. Free radical biology \& medicine 2009, 46:321-326.

11. Lavie L, Hefetz A, Luboshitzky R, Lavie P: Plasma levels of nitric oxide and L-arginine in sleep apnea patients: effects of nCPAP treatment. J Mol Neurosci 2003, 21:57-63.

12. Jordan W, Cohrs S, Degner D, Meier A, Rodenbeck A, Mayer G, Pilz J, Ruther $\mathrm{E}$, Kornhuber J, Bleich S: Evaluation of oxidative stress measurements in obstructive sleep apnea syndrome. J Neural Transm 2006, 113:239-254

13. Phillips SA, Olson EB, Lombard JH, Morgan BJ: Chronic intermittent hypoxia alters NE reactivity and mechanics of skeletal muscle resistance arteries. J Appl Physiol 2006, 100:1117-1123.

14. Bertuglia S, Giusti A: Microvascular oxygenation, oxidative stress, NO suppression and superoxide dismutase during postischemic reperfusion. Am J Physiol Heart Circ Physiol 2003, 285:H1064-1071.

15. Bertuglia S, Giusti A, Del Soldato P: Antioxidant activity of nitro derivative of aspirin against ischemia-reperfusion in hamster cheek pouch microcirculation. Am J Physiol Gastrointest Liver Physiol 2004, 286:G437-443.

16. Manukhina EB, Downey HF, Mallet RT: Role of nitric oxide in cardiovascular adaptation to intermittent hypoxia. Exp Biol Med (Maywood) 2006, 231:343-365.

17. Bertuglia S: Intermittent hypoxia modulates nitric oxide-dependent vasodilation and capillary perfusion during ischemia-reperfusion-induced damage. Am J Physiol Heart Circ Physiol 2008, 294:H1914-1922.

18. Lavie L: Obstructive sleep apnoea syndrome-an oxidative stress disorder. Sleep Med Rev 2003, 7:35-51.

19. Lavie L: Oxidative stress-a unifying paradigm in obstructive sleep apnea and comorbidities. Progress in cardiovascular diseases 2009, 51:303-312.

20. Halliwell B, Gutteridge JM: Oxygen toxicity, oxygen radicals, transition metals and disease. The Biochemical journal 1984, 219:1-14.

21. Wolff SP, Dean RT: Glucose autoxidation and protein modification. The potential role of 'autoxidative glycosylation' in diabetes. The Biochemical journal 1987, 245:243-250.

22. Meneghini R: Iron homeostasis, oxidative stress, and DNA damage. Free radical biology \& medicine 1997, 23:783-792.

23. McClain CJ, Barve S, Deaciuc I, Kugelmas M, Hill D: Cytokines in alcoholic liver disease. Semin Liver Dis 1999, 19:205-219.

24. Savransky V, Reinke C, Jun J, Bevans-Fonti S, Nanayakkara A, Li J, Myers AC Torbenson MS, Polotsky VY: Chronic intermittent hypoxia and acetaminophen induce synergistic liver injury in mice. Exp Physiol 2009, 94:228-239.

25. Martinez D, Fiori CZ, Baronio D, Carissimi A, Kaminski RS, Kim L, Rosa DP, Bos A: Brown adipose tissue: is it affected by intermittent hypoxia? Lipids Health Dis 2010, 9:121.

26. Halpern BN, Pacaud A: Technique of obtaining blood samples from small laboratory animals by puncture of ophthalmic plexus. Comptes rendus des seances de la Societe de biologie et de ses filiales 1951, 145:1465-1466.

27. Anon: AVMA updates its euthanasia guidelines. Veterinary Record 2007, 161:502-502.

28. Anon: AVMA releases updated euthanasia guidelines. JAVMA-Journal of the American Veterinary Medical Association 2007, 231:827-827.

29. Bradford MM: A rapid and sensitive method for the quantitation of microgram quantities of protein utilizing the principle of protein-dye binding. Anal Biochem 1976, 72:248-254

30. Buege J, Aust S: Microsomal lipid peroxidation. Methods Enzymol 1978, 52:302-310. 
31. Misra HP, Fridovich I: The role of superoxide anion in the autoxidation of epinephrine and a simple assay for superoxide dismutase. The Journal of biological chemistry 1972, 247:3170-3175.

32. Boveris A, Chance B: The mitochondrial generation of hydrogen peroxide. General properties and effect of hyperbaric oxygen. Biochem J 1973, 134:707-716.

33. Flohé L, Günzler W: Assays of glutathione peroxidase. Methods Enzymol 1984, 105:114-121.

34. Halliwell B: Free radicals, proteins and DNA: oxidative damage versus redox regulation. Biochem Soc Trans 1996, 24:1023-1027.

35. Beutler E, Duron O, Kelly BM: Improved method for the determination of blood glutathione. The Journal of laboratory and clinical medicine 1963, 61:882-888.

36. Speit G, Hartmann A: The comet assay (single-cell gel test). A sensitive genotoxicity test for the detection of DNA damage and repair. Methods Mol Biol 1999, 113:203-212.

37. Picada JN, Flores DG, Zettler CG, Marroni NP, Roesler R, Henriques JA: DNA damage in brain cells of mice treated with an oxidized form of apomorphine. Brain Res Mol Brain Res 2003, 114:80-85.

38. Granger DL, Anstey NM, Miller WC, Weinberg JB: Measuring nitric oxide production in human clinical studies. Methods Enzymol 1999, 301:49-61.

39. Sleep-related breathing disorders in adults: recommendations for syndrome definition and measurement techniques in clinical research. The Report of an American Academy of Sleep Medicine Task Force. Sleep 1999, 22:667-689.

40. Tanne F, Gagnadoux F, Chazouilleres O, Fleury B, Wendum D, Lasnier E, Lebeau B, Poupon R, Serfaty L: Chronic liver injury during obstructive sleep apnea. Hepatology 2005, 41:1290-1296.

41. Tatsumi K, Saibara T: Effects of obstructive sleep apnea syndrome on hepatic steatosis and nonalcoholic steatohepatitis. Hepatol Res 2005, 33:100-104.

42. Gozal D, Crabtree VM, Sans Capdevila O, Witcher LA, Kheirandish-Gozal L: Creactive protein, obstructive sleep apnea, and cognitive dysfunction in school-aged children. Am J Respir Crit Care Med 2007, 176:188-193.

43. Capdevila OS, Kheirandish-Gozal L, Dayyat E, Gozal D: Pediatric obstructive sleep apnea: complications, management, and long-term outcomes. Proc Am Thorac Soc 2008, 5:274-282.

44. Gozal D, Kheirandish L: Oxidant stress and inflammation in the snoring child: confluent pathways to upper airway pathogenesis and end-organ morbidity. Sleep Med Rev 2006, 10:83-96.

45. Brunt EM: Nonalcoholic steatohepatitis: definition and pathology. Semin Liver Dis 2001, 21:3-16.

46. Park AM, Suzuki YJ: Effects of intermittent hypoxia on oxidative stressinduced myocardial damage in mice. J App/ Physio/ 2007, 102:1806-1814.

47. Dutta A, Ray K, Singh VK, Vats P, Singh SN, Singh SB: L-carnitine supplementation attenuates intermittent hypoxia-induced oxidative stress and delays muscle fatigue in rats. Exp Physiol 2008, 93:1139-1146.

48. Bertuglia S, Reiter RJ: Melatonin reduces microvascular damage and insulin resistance in hamsters due to chronic intermittent hypoxia. $J$ Pineal Res 2009, 46:307-313.

49. Cremonese RV, Pereira-Filho AA, Magalhaes R, de Mattos AA, Marroni CA, Zettler CG, Marroni NP: Experimental cirrhosis induced by carbon tetrachloride inhalation: adaptation of the technique and evaluation of lipid peroxidation. Arquivos de gastroenterologia 2001, 38:40-47.

50. Pavanato A, Tunon MJ, Sanchez-Campos S, Marroni CA, Llesuy S, GonzalezGallego J, Marroni N: Effects of quercetin on liver damage in rats with carbon tetrachloride-induced cirrhosis. Dig Dis Sci 2003, 48:824-829.

51. Tieppo J, Vercelino R, Dias AS, Marroni CA, Marroni N: Common bile duct ligation as a model of hepatopulmonary syndrome and oxidative stress. Arquivos de gastroenterologia 2005, 42:244-248.

52. Pavanato A, Marroni N, Marroni CA, Llesuy F: Quercetin prevents oxidative stress in cirrhotic rats. Dig Dis Sci 2007, 52:2616-2621.

53. Tieppo J, Vercelino R, Dias AS, Silva Vaz MF, Silveira TR, Marroni CA Marroni NP, Henriques JA, Picada JN: Evaluation of the protective effects of quercetin in the hepatopulmonary syndrome. Food Chem Toxicol 2007, 45:1140-1146.

54. Pereira-Filho G, Ferreira C, Schwengber A, Marroni C, Zettler C, Marroni N: Role of $\mathrm{N}$-acetylcysteine on fibrosis and oxidative stress in cirrhotic rats. Arquivos de gastroenterologia 2008, 45:156-162.
55. Sasaki YF, Kawaguchi S, Kamaya A, Ohshita M, Kabasawa K, Iwama K, Taniguchi K, Tsuda S: The comet assay with 8 mouse organs: results with 39 currently used food additives. Mutat Res 2002, 519:103-119.

56. Tice RR, Agurell E, Anderson D, Burlinson B, Hartmann A, Kobayashi H, Miyamae Y, Rojas E, Ryu JC, Sasaki YF: Single cell gel/comet assay: guidelines for in vitro and in vivo genetic toxicology testing. Environ Mol Mutagen 2000, 35:206-221.

57. Hartmann A, Agurell E, Beevers C, Brendler-Schwaab S, Burlinson B, Clay P, Collins A, Smith A, Speit G, Thybaud V, Tice RR: Recommendations for conducting the in vivo alkaline Comet assay. 4th International Comet Assay Workshop. Mutagenesis 2003, 18:45-51.

58. Pavanato MA: Ação protetora da quercetina no fígado de ratos cirróticos. Book Ação protetora da quercetina no fígado de ratos cirróticos 2004, 115 (Editor ed.^eds.). pp. 115. City.

59. Attia A, Ragheb A, Sylwestrowicz T, Shoker A: Attenuation of high cholesterol-induced oxidative stress in rabbit liver by thymoquinone. Eur J Gastroenterol Hepatol 2010, 22:826-834.

60. Tuder RM, Flook BE, Voelkel NF: Increased gene expression for VEGF and the VEGF receptors KDR/Flk and Flt in lungs exposed to acute or to chronic hypoxia. Modulation of gene expression by nitric oxide. J Clin Invest 1995, 95:1798-1807.

61. Suzuki YJ, Jain V, Park AM, Day RM: Oxidative stress and oxidant signaling in obstructive sleep apnea and associated cardiovascular diseases. Free radical biology \& medicine 2006, 40:1683-1692.

62. Haight JS, Djupesland PG: Nitric oxide (NO) and obstructive sleep apnea (OSA). Sleep Breath 2003, 7:53-62.

63. Veasey SC, Davis CW, Fenik P, Zhan G, Hsu YJ, Pratico D, Gow A: Long-term intermittent hypoxia in mice: protracted hypersomnolence with oxidative injury to sleep-wake brain regions. Sleep 2004, 27:194-201.

doi:10.1186/1476-5926-10-1

Cite this article as: Rosa et al: Hepatic oxidative stress in an animal model of sleep apnoea: effects of different duration of exposure. Comparative Hepatology 2011 10:1.

\section{Submit your next manuscript to BioMed Central and take full advantage of:}

- Convenient online submission

- Thorough peer review

- No space constraints or color figure charges

- Immediate publication on acceptance

- Inclusion in PubMed, CAS, Scopus and Google Scholar

- Research which is freely available for redistribution

Submit your manuscript at www.biomedcentral.com/submit
C) Biomed Central 